\title{
The Implementation of Role Play to Improve Speaking Skill of Students at IAIN Kudus
}

\author{
Alfu Nikmah ${ }^{1 *}$, M. Akmalun Niam Zam Zami ${ }^{2}$ \\ 1,2 English Education Department, Institut Agama Islam Negeri Kudus, Kudus, Indonesia
}

\begin{tabular}{|l|l|l|l|}
\hline Contact: & Alfu Nikmah & alfunikmah@stainkudus.ac.id \\
\hline
\end{tabular}

\begin{abstract}
Speaking is one of the important language skills. Speaking relates to daily life as communication tool. It indicates students mastering English. Unfortunately the fact has shown that the students faced many problems to improve their speaking skill because they were accustomed to use their native language in their daily life than using English. The above facts make the lecturer apply some techniques that can motivate students to speak and engage students in encouraging their speaking. One of the techniques that encourage students to speak is role play. This study aims to find out the implementation of role play conducted in the first year students at IAIN Kudus. This study used quantitative research using observation and interview techniques. Based on the result of the study, it can be concluded that the result of this research was satisfying. There are four steps in conducting role play. First is opening , it presents teacher's techniques by giving brainstorming to students, then Main Activity Students do role play using the material that's have been discussed by the lecturer. The third step is Follow Up, it discussed the role play, related to the theme, and finding out the expressions from the role play. The last is closing. Lecturer gave evaluation from the students' performance. Based on students' response, this research claims that it was successful in the effort in improving students' English speaking skill through RolePlay. Students enjoyed in speaking through role play by making dialogue freely and they can express their talent in acting Moreover Role-Play activity could increase the students' self confidence in their speaking performance.
\end{abstract}

KEYWORDS:

English Students Association (ESA);

English Skills;

English Education

Department;

\section{Introduction}

Speaking is perhaps the most important of human skills, and because we do it continuously, we do not often stop to examine the processes involved (Hayrire, 2004). The students often find some problems in practicing English speaking. The problem frequently found is that their native language causes them difficult to use the foreign language. Other reason is because they are lack of 
motivation in practicing the second language in daily conversation. They are also too shy and afraid to take part in the conversation.

Actually Many factors can cause the problem of the students' speaking skills namely the students' interest, the material, and the media among others including the technique in teaching English (Fadilah, 2016). Flowerdew \& Miller (2005) classifies seven causes of difficulty in Speaking process, such as speakers cannot control the speed of delivery, have a limited vocabulary, may fail to recognize the signals which indicate that the speaker is moving from one point to another, giving an example, or may lack contextual knowledge, difficult to concentrate in a foreign language; and may have established certain learning habits such as a wish to understand every word. The existing difficulties create serious problem to the students in speaking process if it does not meet the appropriate treatment. There are many ways that can be done by the students to develop their ability in speaking English. The appropriate method used by the English teacher also supports their interested in practicing their speaking. The opportunity to practice English Speaking for Indonesian students is mainly in the classroom. However, to ask students to practice their speaking in the classroom is a challenging task for an English teacher (Rabbani, Vianty, \& Zuraida, 2016). According to Wahyuningsih \& Dewi (2019), speaking English may be not easy for beginners particularly the undergraduate students from the Islamic Broadcasting Communication Department at State Islamic Institute of Kudus. Therefore teacher developed the innovative teaching using role play in speaking class. Role play is very important in teaching speaking because it gives students an opportunity to practice communicating in different social contexts and in different social roles. In addition, it also allows students to be creative and to put themselves in another person is placed for a while (Fadilah, 2016). Students can create role play using various themes to be interesting story that can build up their speaking through dialogue.

Role play is a technique that allows students to explore realistic situation by interacting with other people in a managed way in order to develop 
experience. According to Ladous in Daniastuti (2018), Role play can be defined as one of whole gamut of communicative techniques which develops fluency in language students, which promotes interaction in the classroom and which increase motivation. Not only peer learning encourage by it, but also sharing between teacher and students of the responsibility for the learning process.

According to Hattings (1993) based on his observation in the conversation class, the role play would seem to be the ideal activity in which students could use their English creatively and it aims to stimulate a conversation situation in which students might find them-selves and give them an opportunity to practice and develop their communication skill. Moreover, role play covers all of English skill all together; listening, speaking, writing and reading. Students will train themselves to create the conversation interesting to attract the audience. Then they will learn to practice their speaking by simulation before giving performance. It indicates that students motivates to give good speaking performance.

Daniastuti (2018) explain that there are five criteria how students achieve better speaking skill,

1. Vocabulary. It is defined vocabulary as total number of word in a language or list of word with their meaning. This criteria has a massive reflection toward people speaking skill in order to express their idea. Lacking of vocabulary cause a gap in every conversation.

2. Pronunciation. It is related reverential meaning by stress and intonation of target language. People who has good speaking skill produce a proper utterance and can be comprehend by listener in every word.

3. Effort is the third criteria to measure a good speaking skill. the quality of student effort is defined as how much voluntary behavior or personal investment a student makes for their education. It has been examined as how often students carry out learning activities, such as taking detailed notes during class", giving proper appreciation on students' effort is very important to bring encouragement in learning process 
4. Fluency is an ability to talk in coherent and fill time with talk. In other definition, this word can be define as "flow" in Latin origin. People with a good speaking skill tend to more fluent, accurate, smooth, lucid, and efficient when they engage conversation.

5. The last criteria is Creativity is the abilities that are most characteristic of creative people. In line with Jarger in Wolf (2012) explains that creativity can be defined as ability to produce something appropriate, generative, and influential. It may not directly measure people speaking skill, but in context of role play and simulation technique. Creativity appreciation provide students encouragement

In defining role play, Donn Byrne as cited in Fadilah (2016) gave comments that role play is a part of drama activity. In details, he described that there are three terms to cover the drama activities. They are mime (mimicrymemorization), role play and simulation. He distinguished the terms as follows:

a. Mime, the participants perform actions without using words (although as we shall see, this activity leads naturally on to talk).

b. Role play, the participant interact either as themselves in imaginary situations.

c. Simulation, this involves role play as defined above. However, for this activity the participants normally discuss a problem of some kind with some setting that has been defined for them. Both role play and simulation are commonly used in foreign language classes to facilitate communicative competence. Whereas mime seems more appropriate as a language game. It is performing actions without using words. For instance, if someone mimes and action, the others try to guess what it is.

Types and Procedures in Using Role Play In view of the persons taking an actor, Gillian in Fadilah (2016) explained that there are several types of role. The first is the roles which correspond to a real need in the students' lives. In this category, it involves such roles as doctors dealing with patients, or salesman traveling abroad. The second type of role is the students play themselves in a 
variety of situations which may or may not have direct experience. The example which include in this category is a customer complaining or a passenger asking for information. The third type is the type that few students will ever experience directly themselves, but it is easy to play because the teachers have such vast indirect experience of them. The television journalist is a good example of this type and it is very useful kind of role taken from real life. The last type is fantasy roles, which are fictitious, imaginary, and possible even absurd.

In case of role play activities, according to Donn Byrne in Fadilah, 2016, p. 203), role play can be grouped into two forms, scripted and unscripted role play. Scripted role play is a role play activity that is done based on the dialogue from the book. Students can imitate the script from the book. In this way, students may change the characters from the script. Then second is unscripted role play. The situations of unscripted role play do not depend on textbooks. It is known as a free role play or improvisation in this type, students can directly determine the language they use in role play.

This paper presents innovative methods and techniques to teach English speaking by using role play conducted in IAIN Kudus. It aims to find out the implementation of role play in teaching English speaking and also find out the students response toward it.

\section{Method}

This study was qualitative in nature. Qualitative study is defined as a study which investigates the quality of relationships, activities, situations, or materials ( Fraenkel, Wallen, \& Hyun in Ma'rifat, 2017). Since it focuses on the quality of certain activity, the data of qualitative study are commonly in the form of words or pictures rather than numbers. These include interview transcripts, filed notes, photographs, audio recordings, videotapes, diaries, personal comments, memos, official records, textbook passages, etc. In order to achieve the purposes of the study, a case study was employed as its research design. A case 
study is used to investigate the phenomenon to answer specific research questions that seeks different kinds of evidence in order to get the best possible answer of the research questions. The reason of using this method is to get an in-depth understanding of how role play implement in teaching speaking English in IAIN Kudus and also reveal their responses towards the use of role play in the process of teaching speaking. This study took place in IAIN Kudus. The data of this study were collected through three instruments including, observation, interview, and written documents. After the data that were gathered from observation, interview, and written documents, they were analyzed and presented in a form of descriptive explanation.

\section{Result}

Speaking as a subject for the third semester has some material conducted in one semester. There are some materials that are arranged in planning of the study for one semester. Role play was implemented in speaking subject.

In one semester there are 16 meeting included midterm test and final test. The conducting of Role play was conducted after the third meeting. The second and the third meeting was discussing the material expression that will be practiced in role play. There are some expression in the speaking syllabi. The purpose that students able to express the expression of like, giving a help, giving suggestion, asking for information and giving for information.

There are some steps found in conducting role play in speaking subject.

\section{Opening.}

Teacher presents the material according to syllabi by giving brainstorming. For the second semester students have some material expression like, asking and giving for a help, giving suggestion, asking for information and giving information

\section{Main Activity}


Students do role play using the material that's have been discussed by the lecturer

\section{Follow Up}

Discussing the role play, related to the theme, and finding out the expressions from the role play.

\section{Closing.}

Lecturer evaluate from the students' performance.

Pre activity or the opening, the lecturer introduced the strategy, telling the objective of the study, then showing the video related to the topic, the topic was giving for a help. After that He did brain storming by asking the students some questions relate to the topic- giving for a help expression. Then he told the students what they have to do. Whilst activity, the researcher asked students to make group about ten, each group consist of 3 and 4 students. Then lecturer asked the students to act as the same as video and scripts of the book. The students were asked to read it, and asked the question if they do not understand. The lecturer then explained how to make dialog or conversation related to the scenario. After the students understand, he distributed the model of dialog related to the scenario, and asked each group to make conversation then practiced in front of the class. The groups were given the time to make the dialogue according to the scenario given. Finally the students practiced the dialog in front of the class. And the other groups paid attention to their friends' performance. Post activity, the lecturer gave feedback on the role play's mistakes and mispronunciation, and correcting them. The lecturer asked the students to analyze the dialogue, to find out the expression from the playing.

\section{Discussion}

Based on the result of the study, it can be analyzed in conducting role play. There are two model in demonstrating role play; role play using script and nonscript role play. 


\section{Scripted Role Play}

Scripted Role play is a role play activity that is done based on the dialogue from the book. Students do not need to make a script. To demonstrate a role play activity based on the dialogue, there are some the procedures is as follows: First, the teacher guides the role play by writing these prompts: (where? / Hospital / when? / Surgery? / thanks). After giving those prompts, teacher give explanation about the meaning of pompoms and give direction to the students to make sentences using the prompts. Students may write the sentences. In this case teacher can direct students to go through the prompts one by one, and get students to give sentences or question for each one. And then, teacher call two students to the front, teacher ask them to conduct role play: one play the role as Mary and the other one is the post office clerk. Students should improvise the conversation using the prompts to help them. They must make conversation that should be similar to the one in the textbook, but not exactly the same; actually the conversation can be shorter than the presentation dialogue. It should just cover the main points indicated by the prompts. Then teacher can call out a few other pairs of students in turn, and ask them to have other conversation based on the prompts. Based on these procedures, the writer views that the ways of organizing this dialogue can be carried out into pairs of students who would improvise a conversation in front of class, in turns. The teacher can also ask the students to practice the conversation privately with their partners before they act it out in front of the class.

This example of student's sheet in scripted role play

Group 1 Script

Asking for a help

Dina : Hi Rina, nice to meet you, thanks for your coming, please sit down.

Rina : Hi Din.... Nice to meet you too 
Dina : let's order to have a meal, I'll treat you, you can order what you want, what do you like?

Rina : Oh really....okay, I like sea food, ill order sea food fried rice, Hamburger then avocado juice

Dina : ok, waiter (calling the waitress), we would like to order 2 sea food fried rice, a hamburger $\mathrm{n} 2$ avocado juice.

Waitress : ok miss, we will come back after 5 minute

Rina : by the why, it is so surprise for me that you invited me here and treat me, what's wrong dina, actually you never treat me before haha......sorry

Dina : Hmmmm....well Rina, could you do me a favour?

Rina : Sure l'll give you a hand, you are my friend

Dina : Really rina....oh...you are really my best friend

Rina : yeah a friend in need is a friend in deed, so what can I do for you?

Dina : would you lend me some money? I need it to pay the tuition fee, I haven't got from my parent. And tomorrow is the last day for payment.

Rina : Oh my god..... So u treat me but you asked me some money.... oh goodness....

Based on the script it is a conversation between two people who the ones need a help and the other give the help. The expression is given the italic word. Based on the data found from the observation and also interview, it can be analyze that the researcher as lecturer observed the implementation of role play. The observation was done to gain or record data about aspects or events which was occurring during the implementation of the strategy. From the transcript can be found the expression of asking a help "could you do me a favor", and giving a help "Sure I'll give you a hand". The use of the expression was quite correct. It was used for asking the money because Dina had a problem. Therefore the implementation of role play of group 1 meet the aspect 
that should be fulfilled by giving expression of help. Then the lecturer also evaluated the students' performance and student's attitudes during the implementation of role play, by using observation checklist and field notes.

\section{Unscripted Role Play}

In contrast to scripted role play, the situations of unscripted role play do not depend on textbooks. It is known as a free role play or improvisation. The students themselves have to decide what language to use and how the conversation should develop. In order to do this activity, good preparation from teacher and students is really necessary.

The example and procedures of unscripted role play which is adapted from Doff (2013) book are as follows: One student has lost a wallet. He/she is at the police station. The other student is the police officer, and asks for details. To brings out this ideas the teacher then asks for the students to discuss with their partner in pair, what probably the police asks to the man, then the students writes on the their note. Then students interact directly in the class using some clue given by the teacher. The teacher in this case give the clue by reminding the expression. In the first meeting the first expression is asking for a help. Then the teacher asks the students to act privately in pair. Then teachers asks some of the students to act in front of the class. After performing the role play, teacher evaluate and write the expression spoken on the board. Then it is analyzed with all of the students to find out the mistakes.

\section{Students Response toward Role Play}

The results showed all of the students being interviewed were happy about the role play used in speaking subject. They were happy because they enjoyed in conducting role play by acting the certain of character. Moreover they were satisfied with teaching by using role play. The implementation of role play can motivate students in create role play to be interesting story, encourage students to speak up and train students to practice their speaking favorably. Four of the students said that they didn't overcome difficulty in the 
teaching and learning process. However, there are four students claimed that they had few difficulties. They thought that they didn't perform perfectly; they needed more time to practice role play. Over all, the students admitted that the use role play in the learning process can help them in learning speaking English. It trained their four skills. It brought positive response from the students.

\section{Conclusion}

This study was concerned with using role play in speaking class. The study was also focus on the students' response towards the use of role play in their English speaking class. There are four stages in implementing role play in speaking class. It covers opening, main, follow up and closing stages. The opening or pre activity, the lecturers discussed with the material, the expression covered for one semester, the main activity is conducting role play. Follow up is lecturers and students' discussion based on the play. Then closing is students evaluation related to the mistake from the pronunciation, intonation, gesture and performance to the play. Then, Students' response towards the use of role play in speaking class was positive. The students motivated to the speaking class because they tend to be creative in speaking performance. By role play students reduce their.

\section{References}

Daniastuti, M. A. (2018). The Effectiveness of Simulation and Role Play Technique to Teach Speaking for High And Low Motivation Students. Leksika, 12(1), 30-36.

Doff, A. (2013). Teaching Speaking (Cambridge English Teacher Professional Development Courses). Cambridge: Cambridge University Press.

Fadilah. (2016). Teaching Speaking by Role-Play Activity. OKARA J ournal of Languages and Literature.

Flowerdew , ., \& Miller, L. (2005). Second Language Listening. Theory and practice. New York: Cambridge University Press.

Hattings, S. D. (1993). Role play. Cambridge: Blaadwell.

Hayrire, K. (2004). Teaching Speaking: Activities to Promote Speaking in a Second Language. The Internet TESL J ournal, 12.

Ma'rifat, D. (2017). A Case Study of Using Songs in Teaching English Vocabulary to Young Learners. J ournal of English and Education, 5, 49-55. 
Rabbani, N., Vianty, M., \& Zuraida. (2016). Using Games To Enhance Speaking Performance of the Seventh Grade Students of Smp Negeri 43 Palembang. Proceeding of the 2nd SULE-IC, 807-821.

Wahyuningsih, S., \& Dewi, S. (2019). Promoting Speaking Proficiency in Broadcasting Through YouTube Project: Perceptions of Undergraduate Students. Proceedings of Third English Language and Literature International Conference, 1-7. https://doi.org/10.4108/eai.27-4-2019.2285332 Wolf, R. (2012). Defining the Concept of Creativity. Netherland. 